\title{
8 THE DYNAMIC IN EAST ASIAN INVESTMENT
}

\section{Roger Farrell and Mari Pangestu}

Over the last half century, Japan has been the dominant economy in East Asia and a key source of trade and investment flows to other economies in the region. ${ }^{1}$ Japanese investment in East Asia provided capital, technology and management flows as firms invested to facilitate trade, to secure resources and energy and to relocate production in response to yen appreciation, rising labour costs and other constraints in the domestic economy. Investors sought to maintain their international competitiveness by relocating production to other East Asian economies as Japan's comparative advantage moved from light industrial products to more sophisticated and higher technology industries such as electronics and motor vehicles.

Led by the internationalisation of Japanese economy from the 1960s and the emergence of China as a leading economy three decades later, East Asia doubled its share of the world economy from 1980 to 2005. A defining characteristic of East Asian economic dynamism has been the rapid expansion of regional trade and investment (Drysdale and Garnaut 1993). These ties have been strengthening, and trade flows between Japan and China exceeded Japanese trade with the United States for the first time in 2003. East Asia has become more important to Japan with exports 
to the region rising from 20 to over 30 per cent in the decade to the mid 2000s and domestic sales of Japanese affiliates also rising (Farrell 2007).

Flows of direct investment into East Asia created extensive production and trade networks, especially in ASEAN, Taiwan, Korea and China, which contributed to growth in these regional economies. Japanese firms, as well as firms from the United States and other foreign direct investment (FDI) source countries, invested to ensure access to other markets (market-seeking FDI); to shift production processes to lower cost locations (efficiencybased FDI); to avoid barriers to trade (tariff-jumping FDI); or to supply services. In many cases, investors have multiple objectives in pursuing foreign direct investment in goods and services industries. In 2000, over forty per cent of Japanese electronics firms invested in China and ASEAN to lower their costs, 10-15 per cent sought to source parts and 15-20 per cent wanted to better secure these markets by establishing local sales or production facilities (Japan, METI 2002).

By 2005, East Asia had developed as an important production base, with its trade and investment pattern dominated by electrical machinery and transport equipment, including parts and components and assembled products - which accounted for around half of regional trade. Regional production chains increasingly switched from import substitution strategies to two-way trade of parts and components produced and assembled in different countries in order to lower costs. The electronics industry was restructured through FDI flows from Japan, the United States and Taiwan and the share of global electronics output of the NIEs and ASEAN economies tripled to over 25 per cent in the two decades to 2005, while electronics production in Japan and the United States fell over the same period.

The pattern of Japanese investment in East Asia reflects Japan's comparative advantage in the manufacturing sector; its firms have imported raw materials, metals and energy as inputs in the production of increasingly sophisticated products. Up until the 1970s, most manufacturing investment overseas went to East Asia and was concentrated on standard products such as textiles, toys, synthetic fibres and consumer electronicswhich had become too costly to produce in Japan. Small to medium enterprises (SMEs) have been active investors; accounting for over 40 per cent of Japanese subsidiaries in East Asia. 


\section{Foreign direct investment in East Asia}

Investment flows have traditionally focused principally on the manufacturing sector, because of East Asia's competitive advantages and partly because of government restrictions on foreign investment in other industries in the primary and service sectors. This trend is changing as deregulation occurs across the region encouraging FDI in the services sector, such as US acquisitions of Japanese financial institutions. However, the region is still an exception to the internationally dominant role of services in global FDI flows. Similarly, indirect or portfolio investment typically flows to established financial markets in North America and Europe. In 2003, the stock of Japanese FDI in East Asia reached 6.7 trillion yen or over US\$700 billion, but the stock of portfolio investment into the region was negligible, at around 2.6 trillion yen out of global portfolio investment of 1,844 trillion yen (Bank of Japan 2004).

Until the 1980s, Japanese manufacturing investment focused on three economies known as newly industrialised economies (NIEs)—South Korea, Taiwan and Hong Kong. The focus of investment then shifted to ASEAN countries, particularly Thailand and Malaysia. From the mid 1990s, China became an important destination for FDI, with Japanese FDI in China's manufacturing sector rising from 5 per cent in 1990 to 43 per cent by 1995. The continual shifting of production bases occurred as host country costs rose with economic development and other locations became more cost-competitive. Firms in Japan also sought to diversify sources of supply, so as to insure against disruptions to their supply chains for raw materials, energy, parts and components, and assembled goods.

Many host countries offered incentives for Japanese investors, who could also receive Japanese tax incentives in support of outward FDI from Japan's declining industries. Often taxes and regulatory costs were lower than in Japan and labour costs a fraction of the domestic equivalent. The higher cost structure in Japan has been less relevant for more technology-intensive industries and production processes which corporations seek to retain domestically as part of their regional strategy and to lower the risk of technology outflow. Continuing changes to costs of production and other factors in East Asia have led Japanese investors to relocate more labourintensive processes from Japan to the NIEs, to ASEAN and to China, 
particularly in response to rising wages, appreciating currencies and the loss of GSP tariff advantages of some locations.

Firms in Japan's 'sunset' industries, such as textiles, were early investors in creating foreign affiliates to relocate labour-intensive processes and lower production costs. Textiles accounted for over 30 per cent of Japanese exports in 1960 , but less than 3 per cent three decades later. To retain competitiveness, Japanese firms such as Toray shifted their factories to ASEAN and China - assisted by a range of government assistance measures including tax concessions and low-interest loans from the Export-Import Bank-and then exported to the home market.

By 2002, East Asia was the location for about 40 per cent of Japanese overseas subsidiaries, from a global total of over 19,000 such firms (Table 8.1). Almost 70 per cent of production affiliates were in East Asia, compared to only one third of sales affiliates. Nevertheless, the region's share of Japanese investment by value was lower, because of the higher incidence of investment by small and medium enterprises in East Asia and the lower incidence of services investment compared to North America and Europe (Table 8.2). While one fifth of Japanese affiliates were located in the United States in 2002, economies in East Asia were important

Table $8.1 \quad$ Japanese subsidiaries by major country, 1960-2000

\begin{tabular}{|c|c|c|c|c|c|c|}
\hline Rank & Country & $1960-70$ & $1971-80$ & $1981-90$ & 1991-2000 & Total \\
\hline 1 & United States & 215 & 474 & 1,785 & 1,191 & 3,733 \\
\hline 2 & China & - & - & 249 & 2,133 & 2,424 \\
\hline 3 & Thailand & 90 & 126 & 490 & 589 & 1,306 \\
\hline 4 & Hong Kong & 71 & 225 & 372 & 487 & 1,176 \\
\hline 5 & Singapore & 20 & 242 & 418 & 471 & 1,165 \\
\hline 6 & United Kingdom & 17 & 109 & 442 & 328 & 918 \\
\hline 7 & Malaysia & 14 & 108 & 337 & 375 & 845 \\
\hline 8 & Taiwan & 109 & 106 & 363 & 257 & 845 \\
\hline 9 & Indonesia & 71 & 225 & 372 & 377 & 665 \\
\hline 10 & Germany & 47 & 122 & 258 & 194 & 632 \\
\hline
\end{tabular}

Note: Table shows the number of Japanese subsidiaries by country.

Source: Calculated from Toyo Keizai Shimposha surveys. Toyo Keizai Shinposha, 2003.

Japanese Overseas Investment: a complete listing by firms and countries, Tokyo. 


\begin{tabular}{|c|c|c|c|c|c|c|}
\hline Table 8.2 & & $\begin{array}{l}\text { FDI } \\
\text { er ce }\end{array}$ & by ma & region & $951-20$ & \\
\hline Period & $\begin{array}{c}\text { North } \\
\text { America }\end{array}$ & $\begin{array}{l}\text { East } \\
\text { Asia }\end{array}$ & Europe & $\begin{array}{c}\text { Middle } \\
\text { East }\end{array}$ & Oceania & Other \\
\hline $1951-60$ & 1.1 & 17.3 & 1.1 & 19.8 & 0.7 & 30.0 \\
\hline $1961-70$ & 25.0 & 21.3 & 19.3 & 8.4 & 7.6 & 18.4 \\
\hline $1971-75$ & 24.3 & 28.1 & 15.2 & 18.3 & 5.3 & 8.8 \\
\hline $1976-80$ & 28.6 & 27.3 & 9.5 & 6.2 & 7.8 & 20.6 \\
\hline $1981-85$ & 36.4 & 20.4 & 13.9 & 1.5 & 3.6 & 24.2 \\
\hline 1986-90 & 32.2 & 23.3 & 13.2 & 3.6 & 5.1 & 22.6 \\
\hline 1991-95 & 46.9 & 12.4 & 18.7 & 0.4 & 4.3 & 17.3 \\
\hline 1996-00 & 39.1 & 19.0 & 26.0 & 0.4 & 3.4 & 12.1 \\
\hline 2001-04 & 24.6 & 16.1 & 40.7 & 0.1 & 2.3 & 16.2 \\
\hline
\end{tabular}

Note: Data refers to new investment flows and excludes reinvestment.

Source: Japan Ministry of Finance, annual. Outward Direct Investment (Country and region), Ministry of Finance, Tokyo. (Available at: http://www. mof.go.jp/english/e1c008.htm).

locations, with 13 per cent in China; 6 per cent in Hong Kong, 7 per cent in Thailand, 6 per cent in Singapore, 4 per cent in Malaysia and 3.5 per cent in Indonesia (Toyo Keizai Shinposha 2003).

Overall, Japanese business affiliates around the world employed around one million persons in 1985, two million in 1995, and 3.7 million a decade later. Employment increased in subsidiaries in Asia, especially in the NIE and ASEAN economies. The East Asian region accounted for 60 per cent of global employment in the mid 2000s and ASEAN and China have been the major centres. By 2005, Japanese subsidiary employment in China increased by 25 per cent to reach one million, the level reached by Japanese subsidiaries in ASEAN (Japan, METI 2005).

By 2000, over half of Japanese firms with overseas production had facilities in China, but many sought to diversify their production bases to avoid over-reliance on one source in case of supply disruptions or political tensions (Table 8.3). From the 1990s, both ASEAN and China were targeted by Japanese medium and small-sized corporations as production, assembly and processing locations for local supply and export to Japan or third-country markets. Japanese firms have been notably cautious investors in China, worried about bilateral political tensions and the possible loss 


\begin{tabular}{lccccr}
\hline Table 8.3 & Japanese overseas affiliates, by type of operations, 2004 \\
\hline Location & $\begin{array}{c}\text { Production } \\
\text { base }\end{array}$ & $\begin{array}{c}\text { Sales } \\
\text { base }\end{array}$ & $\begin{array}{c}\text { Research and } \\
\text { development base }\end{array}$ & $\begin{array}{c}\text { Other } \\
\text { base }\end{array}$ & Total \\
NIEs & 593 & 927 & 17 & 101 & 1,638 \\
ASEAN & 1,146 & 493 & 23 & 93 & 1,755 \\
China & 1,592 & 599 & 63 & 130 & 2,384 \\
Other Asia & 215 & 108 & 4 & 17 & 344 \\
North America & 719 & 614 & 76 & 195 & 1,604 \\
Latin America & 187 & 140 & 2 & 74 & 403 \\
European Union & 444 & 831 & 52 & 113 & 1,440 \\
Central and Eastern Europe & 101 & 69 & 7 & 3 & 180 \\
Other Europe & 15 & 32 & - & 2 & 49 \\
Russia and other & 13 & 21 & - & 5 & 39 \\
Oceania & 50 & 104 & 3 & 29 & 186 \\
Middle East and Africa & 40 & 79 & 2 & 9 & 130 \\
Total & 5,115 & 4,017 & 249 & 771 & 10,152 \\
\hline
\end{tabular}

Note: NIEs-3 are Taiwan, Singapore and South Korea; ASEAN-4 are Malaysia, Thailand, Indonesia and the Philippines. (b) The JBIC survey covered 939 Japanese manufacturing companies, each of which had three or more overseas affiliates and at least one overseas production base, with a response rate of 63.4 per cent in 2004.

Source: Japan Bank for International Cooperation, 2006, Tokyo.

of intellectual property. Capital flows began to increase markedly only in the 2000s after China's accession to the World Trade Organization-a move which significantly liberalised trade and investment flows; set in train a sequence of further deregulations over time; and enhanced investor confidence in China.

Japanese manufacturing FDI in East Asia has been focused on ASEAN and China especially (Figure 8.1) and investors have sought to establish lower cost production activities in this region (Table 8.4). Reflecting this investment pattern, the overseas production ratio of Japanese manufacturing has continued to rise (Table 8.5). The trade pattern in East Asia has been influenced by the sales and production networks created by FDI inflowswhich have formed regional supply chains for manufacturing industry in Japan (see Figure 8.2). In the decade from 1995, Japanese manufacturing 
Figure 8.1 Japanese manufacturing FDI in East Asia, 1989-2003 (100 million yen)

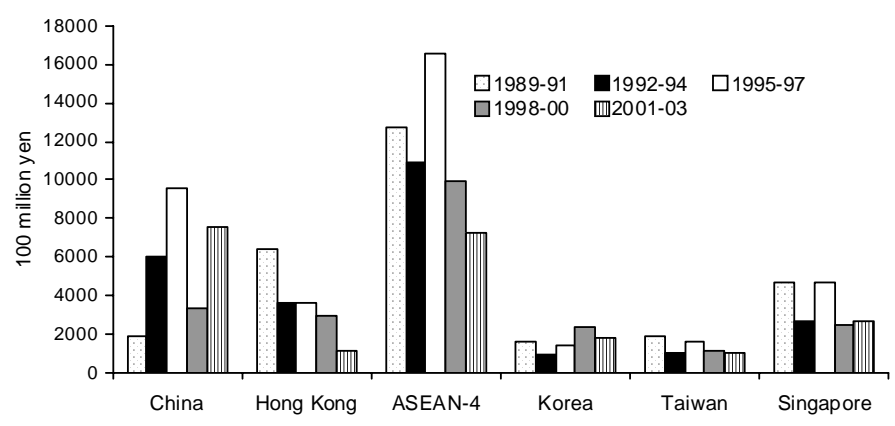

Source: United Nations Conference on Trade and Development, 2003. World investment report, United Nations Conference on Trade and Development, Geneva.

industry exports to overseas affiliates rose from 17 to 35 per cent of total exports from Japan-indicating the trend towards fragmentation within an intrafirm sales and procurement network in the region. The value of exports of manufactures to overseas affiliates rose by 22 per cent in 2004, reaching 20 trillion yen or around US\$175 billion. Exports from overseas affiliates to manufacturing industry in Japan reached 8.7 trillion yen (US\$76 billion).

Similarly, exports from overseas subsidiaries to parents in Japan ('reverse imports') grew from 11.6 per cent to almost 20 per cent of total imports into Japan. Increasingly, final products such as less complex electronics goods are produced in East Asia and then imported and sold directly into the Japanese market by domestic firms. The Asian economic crisis of 1997 led Japanese affiliates to move increasingly towards a greater exportorientation after the collapse of the regional demand during the crisis.

Another related trend has been increased local sales of Japanese affiliates in East Asia, which almost tripled after the Asian crisis to 2000 reaching a new peak as confidence in the ASEAN economies returned. As a result, local and regional sales of Japanese affiliates in East Asia, plus affiliate sales to Japan considerably exceeded imports from Japan to the region, signifying a new maturity in the economic relationship. 


\begin{tabular}{|c|c|c|c|c|c|c|c|c|c|}
\hline \multirow[b]{3}{*}{ Industry } & \multicolumn{9}{|c|}{$\begin{array}{l}\text { Motivations for Japanese foreign direct investment in } \\
\text { East Asia, } 2000\end{array}$} \\
\hline & \multicolumn{3}{|c|}{$\begin{array}{c}\text { China } \\
(2,631 \text { firms }) \\
\end{array}$} & \multicolumn{3}{|c|}{$\begin{array}{c}\text { ASEAN-4 } \\
(3,098 \text { firms })\end{array}$} & \multicolumn{3}{|c|}{$\begin{array}{c}\text { NIEs-3 } \\
(1,835 \text { firms })\end{array}$} \\
\hline & $\begin{array}{c}\text { Lower } \\
\text { cost }\end{array}$ & $\begin{array}{l}\text { Parts } \\
\text { supply }\end{array}$ & $\begin{array}{c}\text { Market } \\
\text { share }\end{array}$ & $\begin{array}{c}\text { Lower } \\
\text { cost }\end{array}$ & $\begin{array}{l}\text { Parts } \\
\text { supply }\end{array}$ & $\begin{array}{c}\text { Market } \\
\text { share }\end{array}$ & $\begin{array}{c}\text { Lower } \\
\text { cost }\end{array}$ & $\begin{array}{l}\text { Parts } \\
\text { supply }\end{array}$ & $\begin{array}{l}\text { Market } \\
\text { share }\end{array}$ \\
\hline Food & 33 & 1 & 23 & 26 & 3 & 18 & 20 & - & 28 \\
\hline Textiles & 53 & 4 & 10 & 44 & 3 & 18 & - & 3 & 18 \\
\hline Wood and $\mathrm{p}$ & 12 & 22 & 27 & 28 & 8 & 12 & - & 25 & 25 \\
\hline Chemi & 28 & 5 & 27 & 27 & 11 & 26 & 26 & 6 & 27 \\
\hline Steel & 31 & 16 & 32 & 26 & 21 & 30 & 27 & 10 & 25 \\
\hline Non-ferrol & 45 & 15 & 17 & 35 & 18 & 22 & 24 & 29 & 21 \\
\hline General & 44 & 4 & 22 & 46 & 11 & 21 & 28 & 9 & 25 \\
\hline Electrical machinery & 42 & 8 & 21 & 46 & 15 & 14 & 35 & 12 & 23 \\
\hline Transport machinery & 28 & 19 & 30 & 34 & - & - & 26 & 15 & 27 \\
\hline Precision machinery & 54 & 4 & 13 & 60 & - & - & 15 & - & 25 \\
\hline Oil, coal & 15 & 23 & 8 & 17 & 8 & 17 & 33 & - & 33 \\
\hline Other manufacturing & 34 & 7 & 24 & 39 & 11 & 18 & 35 & 8 & 22 \\
\hline
\end{tabular}

Note: The MITI survey for 2000 covered 12,243 firms globally, with 7,894 in Asia. The proportion of subsidiaries established for the purpose of research and development, re-exports, or to avoid trade conflict, were very low for all locations.

Source: Japan, MITI, 2001. Basic Survey of the Overseas Business Activities of Japanese Firms, Ministry of International Trade and Industry, Tokyo.

\section{Case study of the Japanese electronics industry in East Asia}

Overall, the basic pattern of production and trade for the electronics industry in East Asia has been for capital and intermediate goods to be imported from Japan and the United States, processed and assembled in the region and then exported to the United States and other major economies_although domestic markets are becoming more important. The electronics industry comprises a range of labour-intensive and capitalintensive production processes in the consumer electronics, industrial machinery and electronics components sub-sectors-which have been 


\section{Table 8.5 Overseas production ratio of Japanese manufacturing, 1985-2007 (per cent)}

\begin{tabular}{lrrrrrr}
\hline Industry & 1985 & 1990 & 1995 & 2000 & 2003 & 2007 \\
Food & 0.9 & 1.2 & 2.6 & 2.8 & 4.9 & n.a. \\
Textiles & 2.7 & 3.1 & 3.5 & 8.6 & 8.4 & n.a. \\
Chemicals & 2.0 & 5.1 & 8.3 & 13.4 & 16.9 & 24.1 \\
Iron and steel & 5.3 & 5.6 & 9.2 & 16.3 & 9.4 & n.a. \\
General machinery & 3.4 & 10.6 & 8.1 & 12.1 & 18.4 & 25.8 \\
Electrical machinery & 7.4 & 11.4 & 16.8 & 21.9 & 38.8 & 45.5 \\
Transport machinery & 5.6 & 12.6 & 20.6 & 31.1 & 28.7 & 35.5 \\
Total manufacturing & 3.0 & 6.4 & 9.0 & 13.4 & 26.1 & 33.2
\end{tabular}

Note: Production ratio equals overseas production divided by total production.

Sources: Japan, METI, annual. Ministry of Economy, Trade and Industry and Japan Bank for International Cooperation, 2006. Survey Report on Overseas Business Operations by Japanese Manufacturing Companies, Tokyo. .

Figure 8.2 Patterns of Japanese production and trade with East Asia (trillion yen)

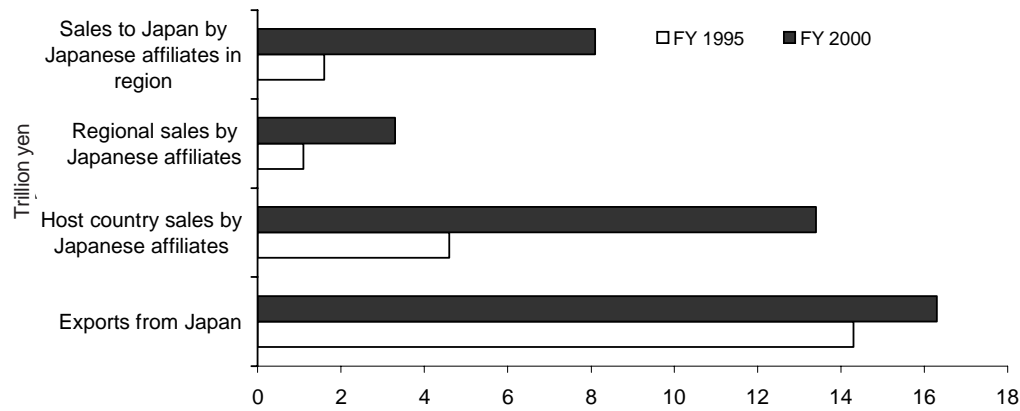

Sources: Japan External Trade Organisation, 2003, Japanese Trade, JETRO, Tokyo; Japan Bank for International Cooperation, 2006; Survey Report on Overseas Business Operations by Japanese Manufacturing Companies, Tokyo; Japan Ministry of Finance, annual; Outward Direct Investment (Country and region), Ministry of Finance, Tokyo. Available at: http://www. mof.go.jp/english/e1c008.htm. 
Table 8.6 Foreign assets of Japanese subsidiaries overseas, 19802001 (US\$ billion)

\begin{tabular}{lrrrr}
\hline Region & 1980 & 1989 & 1995 & 2001 \\
East Asia & 17,083 & 60,859 & 146,140 & 209,322 \\
North America & 24,329 & 158,022 & 223,398 & 299,059 \\
Europe & 10,015 & 130,456 & 137,848 & 167,049 \\
Latin America & 11,993 & 14,663 & 29,175 & 47,298 \\
Others & 9,845 & 21,710 & 24,763 & 3,190 \\
Total & 73,265 & 385,701 & 561,324 & 725,918 \\
\hline
\end{tabular}

Source: Japan, METI, 2002. Ministry of Economy, Trade and Industry and Japan Bank for International Cooperation, 2006. Survey Report on Overseas Business Operations by Japanese Manufacturing Companies, Tokyo, various issues.

relocated according to the labour costs and technological capabilities of economies in East Asia.

The quarterly survey of Japanese overseas affiliates conducted by METI (2004) provides an interesting guide to this relocation and upgrading process (Figure 8.3). In 1997, the year of the Asian economic crisis, around 60 per cent of employees of Japanese electronics affiliates in East Asia were located in the ASEAN-4 (251,000), with 16 per cent in the NIE-3 $(67,000)$ and 25 per cent in China $(108,000)$. By 2003, the share of the ASEAN-4 had increased absolutely to 388,000 - but this now represented only 47 per cent of the regional workforce of the Japanese electronics industry, with China about 45 per cent and the NIE-3 down to 8 per cent.

In this transformation of the Japanese electronics industry's regional production and trade network, total East Asian sales, worth almost 8 trillion yen, grew in both the ASEAN-4 and China at the expense of the NIE-3. Exports to the Japanese market from Japanese affiliates in East Asia have grown over the period from 1.3 trillion yen to 2.4 trillion yen from 1997 to 2003, with China's share rising from 22 to 32 per cent and ASEAN-4's share around 47 per cent—although it rose to almost 56 per cent in 1998 as Japanese firms adjusted to the crisis (Japan, METI 2004).

For East Asia as a whole, intra-regional trade in electrical machinery goods in 2002 reached US $\$ 200$ billion, which accounted for over half of total regional exports-indicating high regional trade intensity and 


\section{Figure 8.3 Japanese electronics industry in East Asia, sales and} exports 1997-2003 (billion yen)

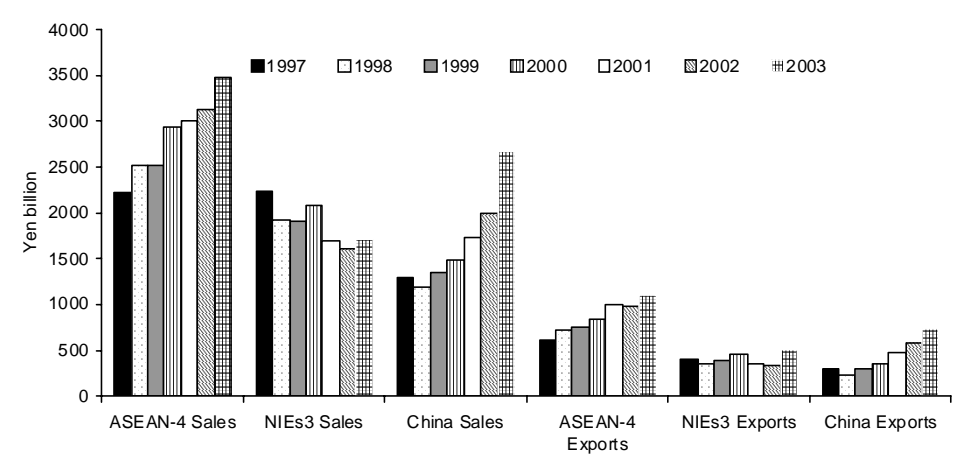

Source: Japan, METI, 2004. Ministry of Economy, Trade and Industry. Quarterly Survey of Business Activities, Tokyo.

complementarity indexes. However, despite increasing trade and investment in East Asia by Japanese electronics firms such as Matsushita, Toshiba and Sony, the profits of these companies have been affected by the rising competitiveness of other manufacturers in East Asia, including in China. In response, a number of electronics firms have expanded cutting-edge electronics investment in Japan, seeking to protect and extend their technological advantages.

\section{Organisational patterns}

The choices of modes for international business expansion generally include exporting, licensing, joint ventures and wholly owned subsidiaries. Initially, many Japanese investments from the 1950s to the 1970 s were joint ventures with local partners, with the aim of gaining knowledge of overseas markets and satisfying restrictions on foreign investment, such as in ASEAN members Malaysia, Thailand and Indonesia. Gradually, higher levels of ownership and control came to be preferred by Japanese firms establishing overseas operations with wholly owned or majority owned unless they were required to form minority joint ventures by the local regulatory or 
political environment, as occurred in ASEAN in the 1970s and China in the 1990s.

In 2000, over 60 per cent of all Japanese subsidiaries in Asia were joint ventures, a comparatively high share because of the historical legacy of foreign investment restrictions in East Asia (Table 8.7). Joint ventures involving small and medium-sized enterprises (with less than 300 employees) were more common than for larger enterprises, due in part to the greater resources available to the latter group of firms. Around half of investments by SMEs were joint ventures (RIETI 2003).

From the 1990s, majority or wholly-owned greenfield investments became more frequent, especially to China and ASEAN, as foreign investment restrictions were eased. Over the decade, they accounted for over 50 per cent of investments, compared to an average of around 35 per cent in the preceding three decades (Delios and Beamish 2002). As China acceded to the WTO and eased trade and investment barriers, it became more popular as a target for Japanese investment-as well as for US, European and Taiwanese investors.

\section{The role of small and medium enterprises}

In early 2002, around 60 per cent of Japanese SMEs were established in Asia, with North America and Europe accounting for a further 29 per cent of subsidiaries of SMEs. In the early 1990s, China attracted almost

\begin{tabular}{|c|c|c|c|c|c|c|c|}
\hline \multirow{2}{*}{$\frac{\text { Table } 8.7}{\text { Joint venture }}$} & \multicolumn{7}{|c|}{ Japanese FDI, mode by country, 2000} \\
\hline & US & Asia & China & ASEAN-4 & NIE-3 & EU & Total \\
\hline$<25$ per cent & 3.3 & 4.3 & 3.0 & 4.5 & 4.5 & 2.3 & 3.8 \\
\hline $25-50$ per cent & 2.8 & 20.4 & 15.4 & 25.8 & 17.7 & 4.7 & 14.4 \\
\hline 50 per cent & 3.3 & 6.6 & 10.0 & 1.8 & 9.8 & 3.1 & 5.3 \\
\hline $50-75$ per cent & 5.7 & 18.8 & 24.1 & 17.0 & 12.3 & 4.3 & 13.7 \\
\hline $75-100$ per cent & 8.6 & 15.5 & 15.6 & 18.3 & 13.1 & 11.2 & 49.1 \\
\hline 100 per cent & 76.3 & 34.4 & 31.9 & 32.6 & 42.7 & 74.4 & 37.5 \\
\hline Number of firms & $1,166)$ & $(3,856)$ & $(1,276)$ & $(1,478)$ & (919) & $(786)$ & $(6,405)$ \\
\hline
\end{tabular}

Source: Japan, METI 2002. Ministry of Economy, Trade and Industry. Quarterly Survey of Business Activities, Tokyo. 
half of SME FDI, followed by Southeast Asia and North America and Europe. The main motivation for investment in Asia for Japanese SMEs has been to import lower costs products to Japan or to sell products to local Japanese affiliates. By contrast, the reason for FDI in Europe and North America has been to sell manufactured products to local enterprises (Japan, METI 2004).

The mode and structure of SME foreign subsidiaries has varied significantly, often reflecting factors such as local foreign investment laws, concern over technology transfer, and the funding abilities of smaller companies. A survey in late 2003 by METI found that over half of SMEs had established independent wholly owned subsidiaries in China and a quarter had majority-owned joint ventures. In North America, almost 90 per cent of SME FDI subsidiaries involved wholly or majority-owned Japanese investment (RIETI 2003).

\section{Financing patterns for Japanese FDI}

Japanese firms have faced a range of options in financing their overseas investment, such as using the capital of the parent company, reinvesting the profits of overseas affiliates, borrowing from Japanese financial institutions in Japan and the host country, or raising bonds. The choice between these options depends upon interest rates in Japan and the host country, foreign exchange risk, the credit rating of the parent and subsidiary, tax considerations, and the depth of the financial market in the host country.

Significant difference are evident in the profitability of Japanese and US multinationals around the world (Itagaki 2002). In the 1970s and 1980 s, the average profitability of Japanese firms (4-6 per cent) was lower than for US firms (10-12 per cent) (Porter 2000). This trend has persisted, and in the early 2000s, for example, profit margins of Japanese-affiliated companies operating in China or ASEAN averaged about 6 per cent, compared to over 15 per cent for US-affiliates companies in the same economies (Japan, METI 2006). The profitability of Japanese firms by region from 1996 to 2004 is shown in Figure 8.4.

This marked difference in operating profits of Japanese affiliates in East Asia has been attributed to different business practices adopted by Japanese 
Figure 8.4 Profitability of Japanese FDI by region, 1996-2004 (per cent)

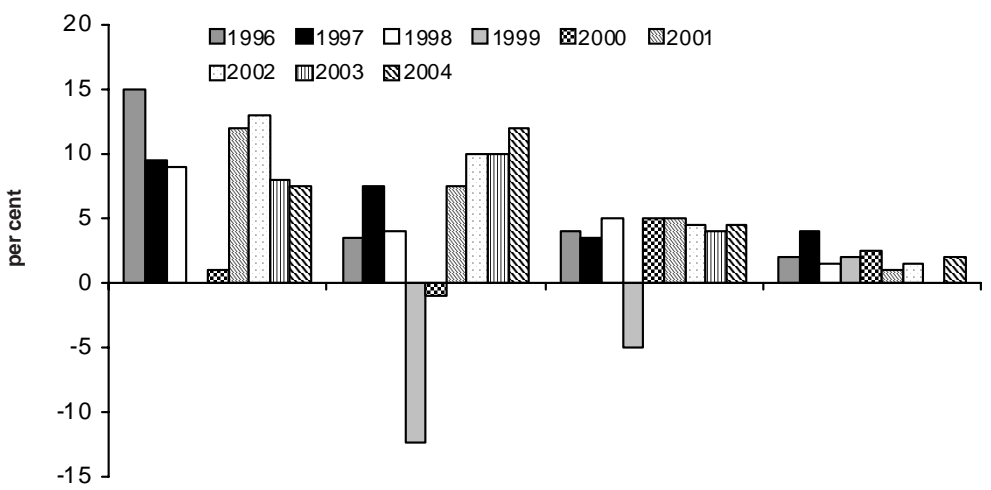

China ASEAN-4 United States European Union

Note: Direct investment profit ratios_-Profits received on direct investment divided by direct investment balances.

Sources: Bank of Japan, 2006. International Balance of Payments Statistics, by Region, Bank of Japan, Tokyo; Japan, Ministry of Economy, Trade and Industry, 2006. White Paper on International Economy and Trade, Tokyo.

affiliates — such as the slower profits arising from using a 'greenfield' model instead of more flexible merger and acquisition strategies of American companies, and the lower tax depreciation available for Japanese affiliates. Another possibility is the reluctance of Japanese managers of affiliates to transfer management responsibilities to local employees adopting instead a management structure that is similar to that in their parent companies (Japan, METI 2006).

In East Asia, funding of Japanese FDI was historically dominated by equity or loan funding, with reinvestment a comparatively minor factor until the 2000s when the profitability of affiliates improved markedly, especially in China. The notable turnaround of the profitability of Japanese FDI in East Asia may be attributable to new estimates by the Bank of Japan, based on balance of payments data rather than industry surveys (Bank of Japan 2006). 
The extent of China's recent growth, at average annual increases in GDP of 10 per cent, is one explanation for the increased profitability of Japanese affiliates in that country. Another is the greater availability of local parts and components in China that has encouraged higher ratios of local procurement and local management of Japanese affiliates, and that may have contributed to higher profitability (Fukao 2007).

\section{Linkages between FDI and ODA}

Since the 1970s, Japan has directed over half of its official development assistance (ODA) to East Asia, reflecting its close political and economic relationship with the region (Figure 8.5). Following the rapid appreciation of the Japanese yen from late 1985, the Japanese government sought to use its extensive and growing ODA program to facilitate the adjustment of Japanese firms and industries to the yen-induced decline in their international competitiveness. As part of this focus, a New Asian Industrial Development Aid Plan was announced by MITI Minister Tamura in 1987 to assist the relocation of labour-intensive manufacturing to low cost sites in Asia (Arase 1995).

Japan became the world's largest aid donor in 1991 and ODA outflows peaked at US $\$ 13$ billion in 2000 although fiscal pressures in the 2000 s led to major cuts to the ODA budget. A significant proportion of these funds were directed to economic infrastructure in East Asia and linked to increasing trade and investment between Japan and the bilateral recipient. Yen loans for roads, bridges, ports or hospitals were used to finance the activities of Japanese construction and engineering firms especially in East Asia, as well as other regions (Japan, MOFA 2003).

Japanese ODA loans and grants were used in ASEAN economies to facilitate the start-up of assembly and manufacturing processes by Japanese firms and local partners. Often government agencies such as MITI negotiated with host government officials to provide incentives for Japanese firms to relocate, while JETRO, JICA and other agencies organised packages of loans, grants and technical assistance that greatly facilitated Japanese manufacturing and other FDI in East Asia (Arase 1995).

The provision of Japanese government guarantees for trade insurance and finance and the role of particular agencies in targeting particular 
Figure 8.5 Distribution of Japanese ODA, by region, 1970-2001 (per cent)

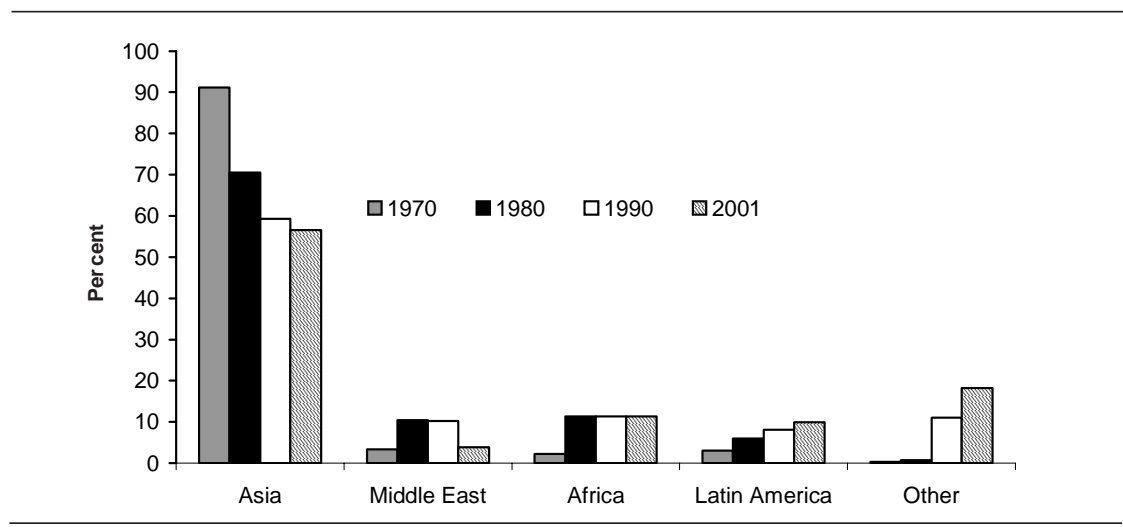

Source: Japan, Ministry of Foreign Affairs, 2003. Official Development Assistance (ODA) White Paper 2002, Tokyo.

projects eased the investment decision of many smaller Japanese manufacturers in industries — such as general machinery and textiles-as did the profusion of information available from Japanese trade, aid and business organisations (Solis 2003). These policy measures effectively represented public subsidies for the internationalisation and relocation of less competitive industries - a kind of defensive form of FDI-which contrasts with the comparative lack of assistance for larger, more competitive firms in the machinery, metals, automotive and electronics industries.

\section{Conclusion}

Over the last fifty years, Japanese foreign direct investment has contributed positively to the East Asian region through the transfer of industrial capacity, employment, capital and technology, all of which are bound up in the FDI package. Since Japan accounted for around half of the East Asian economy for much of this period, trade and investment linkages to the Japanese market were critical to the growth and development of other economies in the region. Japanese manufacturing firms have been among 
the most active investors in East Asia and created sales and production networks in the NIEs, ASEAN and Chinese economies which developed into supply chains across the region.

In the future, it is likely that closer integration between Japan and the rest of East Asia will continue. Already, China is Japan's major trade partner and trade is generally expected to grow further, providing further opportunities for Japanese and other firms in the region. The removal of remaining barriers to trade in goods and services in East Asia, for example through the creation of a consolidating free trade area (absorbing existing FTAs) would further promote closer regional linkages, especially if it included members of political groupings such as ASEAN+3, such as Japan, China, Korea and ASEAN (Pangestu and Gooptu 2003).

As noted by Peter Drysdale two decades ago, economic growth and development has accelerated across the East Asia region as barriers to trade and investment in goods and services across the region have been gradually removed, although many still remain (Drysdale 1988). The future liberalisation of barriers to services trade, for example, would significantly increase regional investment in industries such as banking and finance, telecommunications, commerce, real estate and transport and communications - these are currently inhibited by a range of government restrictions such as on foreign investment.

Partial deregulation in Japan itself has already led to positive capital inflows into the restructuring of less competitive firms in the motor vehicle and financial brokering industries. Similar deregulation, through either multilateral or bilateral trade or investment liberalisation, especially in ASEAN and China, would be likely to greatly boost inward flows of productive foreign direct investment and allow further increases in trade in goods and services across East Asia, to the benefit of all countries in the region. 


\section{Notes}

1 East Asia is generally defined to include China, Japan, Hong Kong, Korea, Taiwan, Brunei, Indonesia, Malaysia, the Philippines, Singapore, Thailand and Vietnam (JETRO 2003).

\section{References}

Arase, D., 1995. Buying Power: the political economy of Japan's foreign aid, Lynne Rienner, London.

Bank of Japan, 2006. International Balance of Payments Statistics, by Region, BOJ, Tokyo. Available at http://www.boj.go.jp.

Beamish, P.W., A. Delios and S. Makino (eds), 2001. Japanese Subsidiaries in the New Global Economy, Edward Elgar, Cheltenham.

Drysdale, P.D. (ed.), 1972. Direct Foreign Investment in Asia and the Pacific, ANU Press, Canberra.

— 1988. International Economic Pluralism, Economic Policy in East Asia and the Pacific, Allen and Unwin, Sydney.

Drysdale, P.D. and Garnaut, R., 1993. 'The Pacific: an application of a general theory of economic integration', in C.F. Bergsten and M. Noland, Pacific Dynamism and the International Economic System, Institute for International Economics, Washington, DC:183-224.

Farrell, R., 2007. Japanese Investment in the World Economy, a study of strategic themes in the internationalisation of Japanese industry, Edward Elgar, forthcoming February 2008.

—_, and Findlay, C., 2002. 'Japan and the ASEAN-4 automotive industry', East Asian Economic Perspectives, ICSEAD, March.

Fukao, K., 2007. 'Plant Turnover and TFP Dynamics in Japanese Manufacturing', seminar presented at the Australian National University, Canberra, 8 February.

Japan Bank for International Cooperation, 2006. Survey Report on Overseas Business Operations by Japanese Manufacturing Companies, Japan Bank for International Cooperation, Tokyo.

Japan External Trade Organisation (JETRO) 2004. JETRO, Tokyo. Expanding Japanese presence in East Asia, JETRO Working Paper No. 1 (http://www.jetro.go.jp/it/e/press/2004/apr21.html). 
Japan, Ministry of Economy, Trade and Industry (METI), 2003. Basic Survey on Foreign Direct Investment (Kaigai Toushi Tokei Souran), METI, Tokyo.

—, 2002-4. Quarterly Survey of Business Activities, Tokyo.

— 2004 . White Paper on Small and Medium Enterprises in Japan, Tokyo.

- 2006. White Paper on International Economy and Trade, Tokyo.

Japan, Ministry of International Trade and Industry (MITI), 1991-01. Basic Survey of the Overseas Business Activities of Japanese Firms (Kaigai toshi tokei soran), Tokyo.

Japan Ministry of Finance, annual. Outward Direct Investment (Country and region), Ministry of Finance, Tokyo. (Available at: http://www. mof.go.jp/english/e1c008.htm).

Japan, Ministry of Foreign Affairs, 2003. White Paper on Japan's ODA (Seifu Kaihatsu Enjo Hakusho), Tokyo.

Kohama, H., 2003. 'Aid, trade and FDI for economic development in East Asia', in H. Kohama, (ed.), External Factors for Asian Development, Japan Institute of International Affairs, Singapore.

Pangestu, M. and Gooptu S., 2003. 'New regionalism: options for China and East Asia', in Krumm et al. (eds), East Asia Integrates: a trade policy agenda for shared growth, World Bank, Washington, DC. Available at http://www.Inweb18worldbank.org.

Research Institute for Economy, Trade and Industry (RIETI), 2003. Survey of Overseas Business Activities of Small and Medium Enterprises, Tokyo, November.

Solis, M., 2003. 'The politics of self-restraint: FDI subsidies and Japanese mercantilism', The World Economy, 26(2):153-80.

Toyo Keizai Shinposha, 2003. Japanese Overseas Investment: a complete listing by firms and countries, Tokyo.

Toyo Keizai Shimposha, annual. Japanese Overseas Investment, Toyo Keizai Shimposha, Tokyo.

United Nations Conference on Trade and Development, 2003. World investment report, United Nations Conference on Trade and Development, Geneva. 